\title{
The Independence Rule in Standby Letters of Credit
}

In modern commercial transactions, various devices are used to ensure performance by the contracting parties. ${ }^{1}$ One of the more frequently used devices is the letter of credit. A letter of credit is a promise by the "issuer" (usually a bank), ${ }^{2}$ made at the request of a "customer," 3 that the issuer will honor drafts or other demands for payment made by the "beneficiary" after the beneficiary has complied with the conditions set forth in the letter of credit. ${ }^{5}$ Once the beneficiary has presented documents conforming to the conditions specified in the letter of credit, the issuing bank must pay the beneficiary. ${ }^{6}$ Under the "independence rule," the issuer's obligation to pay upon a conforming demand is unaffected by any claims that the customer may have against the beneficiary on the underlying contract. ${ }^{7}$

At one time, the letter of credit was most commonly used in conjunction with the sale of goods between geographically distant parties. $^{8}$ In such transactions, the seller (beneficiary) receives pay-

1 Such devices include the traditional letter of credit, the guarantee, and the performance bond. See generally J. WHITE \& R. SUMMERS, HANDBOOK OF THE LAW UNDER THE UNIForm CoMmercial CODE $\S \S 18-1,18-2$ (2d ed. 1980).

2 Although an issuer may be a "bank or other person," see U.C.C. § 5-103(1)(c) (1978), in this comment, the issuing party is always assumed to be a bank.

${ }^{3}$ Id. $\S 5-103(1)(\mathrm{g})$.

Id. $\$ 5-103(1)(\mathrm{d})$.

- $I d$. $\$ 5-103(1)(a)$. The letter of credit is usually payable upon presentation of specified documents to the issuer. See R. Braucher \& R. Riegert, Introduction to Commercial Transactions 358-61 (1977); J. White \& R. Summers, supra note 1, § 18-1, at 704-08.

- Under the doctrine of strict compliance, if there is any discrepancy between the draft that the beneficiary presents to the issuer and the specifications in the letter of credit, the issuer is permitted to dishonor the draft. See Note, Letters of Credit: A Solution to the Problem of Documentary Compliance, 50 FordhaM L. REv. 848, 855 n.37 (1982). In fact, the issuer may be liable to the customer or be barred from obtaining reimbursement if it pays on a nonconforming demand. See Henry Harfield, Bank Credits and Acceptances 105 (5th ed. 1974). Some courts have begun substituting a doctrine of "substantial compliance," but this trend has been strongly criticized. See Dolan, Strict Compliance with Letters of Credit: Striking a Fair Balance, 102 Banking L.J. 18 (1985).

2 See J. White \& R. Summers, supra note 1, § 18-2, at 711-12. This "independence rule" has been called the key to the commercial vitality of the letter of credit. See, e.g., United States v. Sun Bank, 609 F.2d 832, 833 (5th Cir. 1980); Pringle-Associated Mortgage Corp. v. Southern Nat'l Bank, 571 F.2d 871, 874 (5th Cir. 1978).

${ }^{8}$ H. HARfield, supra note 6, at 18-19; J. White \& R. Summers, supra note 1, § 18-1, at 
ment from the issuing bank when he presents a demand and a bill of lading indicating that he has shipped the goods to the buyer (customer). ${ }^{\circ}$ Traditionally, because the bank's obligations were considered to be independent of the beneficiary's performance on the underlying contract, the bank was not allowed to determine whether the seller had actually shipped the goods or whether the goods conformed to the requirements of the contract. In Sztejn $v$. Henry Schroder Banking Corp. ${ }^{10}$ the court carved out an exception to the rule of absolute independence by holding that the issuer is permitted to dishonor the beneficiary's demand for payment if there has been "fraud in the transaction." Courts applying this exception to "traditional"12 letters of credit have generally permitted dishonor (or enjoined payment) only where they have found that the beneficiary's actions constituted "egregious" fraud of the kind involved in Sztejn. ${ }^{13}$

The validity of the rules worked out in traditional letter of credit law has been brought into question by the expanding use of letters of credit in situations that differ from the one just described. Increasingly, American companies have used a variation of the letter of credit, known as the "standby" letter of credit, in both domestic and international commercial transactions. ${ }^{14}$ The standby letter of credit differs from the traditional letter of credit in that the beneficiary may draw on the standby letter of credit only after

704.

- J. White \& R. SummerS, supra note 1, § 18-1, at 704-08.

10177 Misc. 719, 31 N.Y.S.2d 631 (Sup. Ct. 1941).

11 Id. at 721-23, 31 N.Y.S.2d at 634-35.

12 Letters of credit that are used to finance commercial transactions are commonly referred to as "commercial" letters of credit. See H. HARFIELD, supra note 6, at 26-27. This comment will refer to instruments that are used to finance the sale of goods as "traditional" letters of credit, however, to distinguish them from another category of commercial letter of credit-the "direct pay" letter of credit, see infra note 14.

13 See, e.g., United Bank Ltd. v. Cambridge Sporting Goods Corp., 41 N.Y.2d 254, 260 61, 360 N.E.2d 943, 949, 392 N.Y.S.2d 265, 271 (1976); see generally Harfield, Enjoining Letter of Credit Transactions, 95 BANkING L.J. 596 (1978) (arguing that the Sztejn exception is a narrow one).

14 See Verkuil, Bank Solvency and Guaranty Letters of Credit, 25 Stan. L. Rev. 716, 717 (1973); Note, The Role of Standby Letters of Credit in International Commerce: Reflections After Iran, 20 VA. J. INT'L L. 459, 467 (1980) (in 1975, standby letters of credit amounting to more than $\$ 11.7$ billion were outstanding in the United States; by 1978, five banks alone had outstanding standby letters of credit totaling $\$ 12.6$ billion). A third kind of letter of credit, sharing some features of each of the other two, also exists. Under modern "direct pay" letters of credit, the customer will expect from the outset that the letter of credit will be used as the payment mechanism (as with traditional letters of credit) but may not require that a bill of lading or similar document generated by a third party be presented to the issuer. Presumably, these instruments are governed by the traditional Sztejn doctrine. 
the customer defaults on the underlying contract. ${ }^{15}$ For example, in connection with the sale of goods or services, the purchaser might require the seller or provider of the services to obtain a standby letter of credit in the purchaser's favor. The condition for payment under the letter of credit would be the presentment to the issuing bank of a draft and a written statement that the seller had failed to perform (or had performed inadequately). The amount of money payable under the letter of credit would be a percentage of the contract price, and payment under the standby letter of credit would serve as immediate compensation to the purchaser for any damages he may have suffered from the other party's nonperformance. ${ }^{16}$ This form of letter of credit has been frequently used in contracts between Western suppliers of goods and services and Middle Eastern purchasers. ${ }^{17}$

Recent cases involving the Islamic Government of Iran have generated controversy over the proper application of the "fraud in the transaction" exception to standby letters of credit. ${ }^{18}$ While

${ }_{15}$ See, e.g., Dynamics Corp. v. Citizens \& S. Nat'l Bank, 356 F. Supp. 991, 993-94 (N.D. Ga. 1973) (standby letter of credit payable upon customer's failure to deliver goods); Colorado Nat'l Bank v. Board of County Comm'rs, 634 P.2d 32, 34 (Colo. 1981) (standby letter of credit payable upon customer's failure to perform under construction contract); Intraworld Indus. v. Girard Trust Bank, $461 \mathrm{~Pa} .343,348-49,336$ A.2d 316, 319 (1975) (standby letter of credit payable upon customer's failure to pay rent).

${ }^{16}$ See Dominick Policano, Letter of Credit Guidebook 127 (1983).

17 Garman, Standby Letters of Credit and Guarantees: Do We Understand What We're Doing?, J. Com. Bank Lending, Apr. 1978, at 3; see, e.g., cases cited infra note 18 (involving the Iranian Government).

18 Prior to the Iranian Revolution, Iran provided a lucrative market for Western sellers of high technology goods and services. Contracts between American companies and the Imperial Government of Iran typically required the companies to procure standby letters of credit in favor of an Iranian bank. See Kimball \& Sanders, Preventing Wrongful Payment of Guaranty Letters of Credit-Lessons from Iran, 39 Bus. LAw. 417, 419 (1984). This arrangement enabled the Imperial Government to be compensated in the amount of the standby letter of credit upon its written certification that the seller was in default. These contracts also typically provided that all disputes arising between the parties were to be resolved in Iranian courts. See Note, supra note 14, at 475.

The fall of the Imperial Government resulted in the disruption of these contracts. The new Islamic Government was hostile to American business and was not interested in the completion of the contracts. The Islamic Government demanded payment under the letters of credit even though it appeared that the American contractors were not responsible for their failure to complete the contracts. This situation prompted criticism of the independence rule in standby letters of credit. See Gable, Standby Letters of Credit: Nomenclature Has Confounded Analysis, 12 Law \& Pol'y INT'L Bus. 903, 944-45 (1980); Note, "Fraud in the Transaction": Enjoining Letters of Credit During the Iranian Revolution, 93 Harv. L. REv. 992, 1014-15 (1980); see also Comment, Enjoining the International Standby Letter of Credit: The Iranian Letter of Credit Cases, 21 Harv. INT'L L.J. 189, 204-10 (1980) (“overly rigid application of the independent contracts rule threatens results counterproductive to the policy of the rule"). But see Note, supra note 14, at 493-94, 495-96 (defending, in large 
early attempts to enjoin payment under standby letters of credit in these cases were met with strong judicial affirmances of the independence rule, ${ }^{19}$ courts in later cases (involving both Iranian and non-Iranian transactions) have shown a greater willingness to expand the "fraud in the transaction" exception beyond the limits within which it has traditionally been employed. ${ }^{20}$ The courts, however, have generally avoided express statements of the standard of fraud they are using and have arrived at inconsistent results. ${ }^{21}$

This comment examines the problem of defining the fraud in the transaction exception and applying it to cases involving standby letters of credit. The comment first examines the function of the standby letter of credit in modern commercial transactions and demonstrates how this function differs from that served by either the traditional letter of credit or two other common security devices, the performance bond and the cash deposit. The comment then explores and criticizes two recent proposals for an expanded definition of the fraud in the transaction exception as applied to standby letters of credit. Finally, the comment develops a specific standard for the fraud in the transaction exception as applied to standby letters of credit: a customer should be able to enjoin payment on a standby letter of credit only where there is no reasonable basis for the beneficiary's demand and the customer lacks an

part, the utility of the independence rule). Judicial criticism focused primarily on the fact that under a strict application of the independence rule, Iran would be able to obtain payment even though the American companies were innocent of any wrongdoing and even though the xenophobia of Iran's judicial system had taken away any meaningful legal remedy. See, e.g., Harris Corp. v. National Iranian Radio \& Television, 691 F.2d 1344, 1355-56 (11th Cir. 1982); Itek Corp. v. First Nat'l Bank, 511 F. Supp. 1341, 1350-51 (D. Mass. 1981), vacated on other grounds, 704 F.2d 1 (1st Cir. 1983); Stromberg-Carlson Corp. v. Bank Melli, 467 F. Supp. 530, 532-33 (S.D.N.Y. 1979).

19 See, e.g., American Bell Int'l v. Islamic Republic of Iran, 474 F. Supp. 420, 424-25 (S.D.N.Y. 1979) (refusing to infer fraud from allegations that the Iranian Government repudiated the contract but still demanded payment under the standby letter of credit); see also Note, supra note 14, at 493.

${ }^{20}$ See, e.g., Roman Ceramics Corp. v. Peoples Nat'l Bank, 714 F.2d 1207, 1212-13 (3d Cir. 1983) (discussed infra notes 73-84 and accompanying text); Harris Corp. v. National Iranian Radio \& Television, 691 F.2d 1344, 1354-56 (11th Cir. 1982) (allowing a preliminary injunction where the beneficiary's demand "was made in a situation that was subtly suggestive of fraud").

${ }^{21}$ Compare First Arlington Nat'l Bank v. Stathis, 90 Ill. App. 3d 802, 808, 413 N.E.2d 1288,1294 (1980) (holding that beneficiary's certification to the issuing bank that a promissory note was due and unpaid was not fraudulent even though the beneficiary had released the parties from liability on the note), with Roman Ceramics Corp. v. Peoples Nat'l Bank, 714 F.2d 1207, 1214-16 (3d Cir. 1983) (certification that invoices were unpaid held fraudulent because the beneficiary was deemed to have been paid for the invoices under a subsequent agreement between the parties). 
adequate alternative remedy.

\section{Analysis of the Standby LetTer of Credit}

Standby letters of credit and traditional letters of credit are both mechanisms for allocating risks among the parties in commercial transactions. By placing in the hands of a neutral third party the responsibility for making payment when certain conditions are met, one party to a transaction is able to avoid the risk of nonpayment or nonperformance. The standby letter of credit differs from the traditional letter of credit, however, in the method by which it allocates the risks among the parties. The traditional letter of credit usually requires a third party to generate some of the documents that the beneficiary must present to the issuer (usually a bill of lading); ${ }^{22}$ under the standby letter of credit, the beneficiary usually generates all of the necessary documents himself (usually a simple statement that the customer is in default). ${ }^{23}$

The standby letter of credit thus involves a greater risk of improper demand than the traditional letter of credit, ${ }^{24}$ both for the customer and for the issuing bank. ${ }^{25}$ Because the independence rule prohibits the bank from inquiring into the truth of the beneficiary's assertion, ${ }^{26}$ the customer faces a risk that it will have to

${ }^{22}$ See H. HARFIELD, supra note 6, at 57. In addition to a bill of lading, the letter of credit may also require a commercial invoice or an insurance policy covering the goods. Id.

23 See D. Policano, supra note 16, at 127-28.

24 See Garman, supra note 17, at 9; Symons, Letters of Credit: Fraud, Good Faith and the Basis for Injunctive Relief, 54 TuL. L. REv. 338, 343 (1980); Note, supra note 18, at 1011-12.

${ }^{25}$ Although the bank is always entitled to reimbursement from the customer if it has honored a demand conforming to the terms of the letter of credit, see U.C.C. \& 5-114(3) (1978), it assumes the risk of the customer's insolvency. Thus, any increased risk to the customer also increases the risk to the bank. See Garman, supra note 17, at 9. The bank is free, however, to demand that the customer provide it with security to protect against that risk; when this is done, the customer effectively assumes the risk of an improper demand.

The efficacy of such security arrangements between banks and customers was at one time made doubtful by the decision in Twist Cap, Inc. v. Southeast Bank, 1 Bankr. 284 (Bankr. M.D. Fla. 1979). In that case, the bankruptcy court held that it could enjoin payment under a standby letter of credit if the bank is protected by a security interest in the assets of a bankrupt customer. Id. at 285-86. Subsequent cases and commentary, however, have uniformly rejected the analysis in Twist Cap. See, e.g., Page v. First Nat'l Bank (In re Page), 18 Bankr. 713, 715 n.3 (D.D.C. 1982); North Shore \& Cent. Ill. Freight Co. v. American Nat'l Bank (In re North Shore \& Cent. Ill. Freight Co.), 30 Bankr. 377, 379 n.1 (Bankr. N.D. Ill. 1983); Planes, Inc. v. Fairchild Aircraft Corp. (In re Planes, Inc.), 29 Bankr. 370, 371 (Bankr. N.D. Ga. 1983); Baird, Standby Letters of Credit in Bankruptcy, 49 U. CHr. L. REv. 130 (1982).

${ }^{28}$ See, e.g., Bank of Newport v. First Nat'l Bank \& Trust, 687 F.2d 1257, 1261 (8th Cir. 1982); Cappaert Enters. v. Citizens \& S. Int'l Bank, 486 F. Supp. 819, 826 (E.D. La. 1980). 
reimburse the bank for making a payment that was unjustifiably demanded. The bank's risk of loss is also increased because, unlike a bank issuing a traditional letter of credit, it receives no bill of lading. ${ }^{27}$ In a traditional letter of credit transaction involving the sale of goods, one of the documents that must be presented for payment is a bill of lading, which gives the bank title to the goods ${ }^{28}$ and allows the bank to claim the goods if the customer refuses to reimburse the bank. ${ }^{29}$ Without such a security interest, the bank's only recourse is against the customer himself..$^{30}$ Because of these increased risks, the standby letter of credit is analytically distinct from the traditional letter of credit.

The standby letter of credit can also be compared with another device that is commonly used to allocate risks among parties in commercial transactions-the performance bond. Both devices are used to protect a party against the risk of nonperformance of another party's contractual obligations. Nevertheless, standby letters of credit differ in several important respects from performance bonds. ${ }^{31}$ A performance bond is issued by a surety company, a private firm, or an individual, rather than by a bank, and guarantees a buyer of goods or services that the seller (the principal) will perform. ${ }^{32}$ A surety's obligation is secondary to that of the principal, however, and the surety becomes liable only when the principal has in fact defaulted on its obligation. Thus, unlike the issuer of a standby letter of credit, the surety does not pay the buyer automatically upon the buyer's assertion that the seller has not performed: it may first investigate the truth of the assertion. If the surety determines that the seller has fulfilled the contract, then it may refuse to pay the buyer. ${ }^{33}$ The surety may also assert any defenses against the buyer that would be available to the principal. ${ }^{34}$ Furthermore, the surety retains the option of actively intervening

27 See generally Garman, supra note 17 , at 9 .

${ }^{28}$ See U.C.C. $\$ 7-502(1)$ (1978) (holder of a negotiable document of title, which includes a bill of lading, see U.C.C. \$ 7-104(1) (1978), has title to the goods covered by the document).

29 See id. \& 7-502(1).

so The bank, however, may have protected itself with a security interest in assets belonging to the customer. See supra note 25.

${ }^{31}$ See Garman, supra note 17, at 4.

32 In a performance-bond transaction, the surety is analogous to the issuer of a standby letter of credit, the principal is analogous to the customer, and the party who benefits from the guarantee is analogous to the beneficiary.

ss See Arnold \& Bransilver, The Standby Letter of Credit-The Controversy Continues, 10 U.C.C. L.J. 272, 279-80 (1978); Note, supra note 14, at 470-71.

34 See Arnold \& Bransilver, supra note 33, at 279 n.28; Note, supra note 14, at 470 n.76. 
to ensure performance either by demanding that the seller remedy the defect in its performance or by completing the contract itself. ${ }^{35}$

The standby letter of credit differs from the performance bond in the way in which it protects a buyer against the risk of nonperformance. The standby letter of credit allows the beneficiary to recover damages simply by asserting that the customer has defaulted on the contract; except where the fraud in the transaction exception applies, ${ }^{36}$ the issuer is not permitted to refuse payment based either on its belief that the beneficiary's assertion is false or on the existence of any defenses that the customer may have on the underlying contract. For a number of reasons, this basic difference between the standby letter of credit and the performance bond makes the standby letter of credit potentially more useful to the beneficiary than the performance bond. First, the beneficiary benefits from the greater "automaticity and brevity" of payment under the standby letter of credit: ${ }^{37}$ the bank may inspect only the tendered documents, and payment will not be delayed by the bank's investigation of the underlying contract. Second, the standby letter of credit is more flexible than the performance bond because it can be used in a wider variety of transactions. ${ }^{38}$ Third, the administrative expenses involved with a standby letter of credit may be lower than those involved with a performance bond, thus reducing the cost of a standby letter of credit; ${ }^{39}$ because the bank is only responsible for scrutinizing the documents presented upon demand, and because the bank will often already be very familiar with the customer's creditworthiness and with the underlying transaction, it will often be able to avoid incurring the additional or duplicative expenses of investigating and monitoring the underlying contract. ${ }^{40}$ Moreover, the standby letter of credit has the advantage that the bank incurs a much lower risk of becoming embroiled in litigation with the beneficiary than does a surety. ${ }^{41}$ Finally, the standby let-

35 Garman, supra note 17 , at 4-5.

s8 Cf. U.C.C. $\$ 5-114(2)$ (1978) (where there is fraud in the transaction, issuer may honor demand for payment).

${ }^{37}$ Becker, Standby Letters of Credit and the Iranian Cases: Will the Independence of the Credit Survive?, 13 U.C.C. L.J. 335, 339 (1981).

${ }^{38}$ See Baird, supra note 25, at 135-36 \& n.22; Dolan, supra note 6, at 19-20; Lambert, "Clean Credit," Credit \& Fin. MgmT., June 1981, at 18.

${ }^{38}$ Garman, supra note 17, at 8-9.

10 See D. Policano, supra note 16, at 149 (standby letters of credit are less expensive than performance bonds).

41 See Becker, supra note 37, at 339 (because the bank's only legal duty is to scrutinize the documents, rather than the facts behind the documents, risk of litigation is reduced). A related advantage is that the standby letter of credit reduces the probability of judicial 
ter of credit allows parties to take advantage of the financial soundness of banking institutions; while banks are free to issue standby letters of credit, they are generally forbidden from issuing performance bonds. ${ }^{42}$

While the standby letter of credit offers a number of potential advantages over a performance bond, it also increases the risks to the bank and customer. Unlike a performance bond, a standby letter of credit gives the issuing bank no control over the underlying contract and no right to refuse payment based on its opinion that the customer has properly performed. ${ }^{43}$

In view of the relative positions of the beneficiary, the seller, and the issuing bank, the standby letter of credit is more analogous to a cash deposit left with the beneficiary than it is to the traditional letter of credit or to the performance bond. ${ }^{44}$ Because

involvement, thus enabling the parties to evaluate the risks involved with a standby letter of credit more accurately. The desire to minimize judicial involvement is also a motivating factor behind the rule that the documents presented to the issuing bank must strictly comply with the terms of the letter of credit. See Consolidated Aluminum Corp. v. Bank of Va., 544 F. Supp. 386, 396 (D. Md. 1982) (the rule of strict compliance provides certainty of payment to the beneficiary and allows the issuing bank to evaluate its risks accurately). Colorado Nat'l Bank v. Board of County Comm'rs, 634 P.2d 32 (Colo. 1981), for example, demonstrates that courts will not investigate the "purpose" of the standby letter of credit. In that case, the customer planned to develop a mountain recreational community. He received approval from the county, conditioned on his obtaining from a bank three standby letters of credit to ensure completion of some roads in accordance with certain specifications. The county was entitled to draw on the standby letters of credit by submitting to the bank fifteen-day sight drafts accompanied by a signed statement that the customer had failed to make all the required improvements on the roads. The customer, however, never even began constructing the roads. The county made conforming demands on the letters of credit, but the issuing bank refused to pay on the ground that "the County would receive a windfall since it had not expended or committed to spend any funds to complete the road improvements specified in the subdivision improvements agreements." Id. at 35.

The court held that the bank had no right to refuse payment based on a challenge to the beneficiary's intended use of the funds. The only condition of payment specified in the letter of credit was that the county certify that the customer had failed to make the improvements. If the parties had wanted to limit the situations in which the standby letter of credit could be paid, they could have provided for further conditions in the letter of credit, such as a requirement that the county certify that the customer had actually completed its construction but that the specifications had not been met. Id. at 38-39.

42 See, e.g., H. HARFIELD, supra note 6, at 163-65; see also Kimball \& Sanders, supra note 18, at 417 n.1; Lord, The No-Guaranty Rule and the Standby Letter of Credit, 96 BANking L.J. 46, 47 (1979); Note, supra note 14, at 471.

13 Garman, supra note 17 , at 6.

14 See Corporacion de Mercadeo Agricola v. Mellon Bank Int'l, 608 F.2d 43, 50 (2d Cir. 1979) (Gurfein, J., dissenting) (arguing that the normal standby letter of credit, where payment is predicated on simple notice by the beneficiary, is equivalent to a cash deposit); see also New York Life Ins. Co. v. Hartford Nat'l Bank \& Trust Co., 173 Conn. 492, 503-05, 378 A.2d 562, 568 (1977) (upon the seller's default and the proper presentation of documents, the beneficiary has a right to expect a standby letter of credit to become as good as cash). 
the beneficiary generates all the documents necessary to obtain payment, he has the power to appropriate the funds represented by the standby letter of credit at any time. Although the customer may sometimes have payment enjoined when fraud is present, he is obligated to reimburse the bank if the bank has made a payment in good faith, even upon a fraudulent demand. ${ }^{45}$ And because many standby letters of credit contain no provision requiring notice to the customer before the beneficiary receives payment, ${ }^{46}$ the injunction remedy that theoretically is available under the fraud in the transaction exception would often prove useless.

Even though the standby letter of credit is functionally equivalent to a cash deposit, it differs from a cash deposit because the customer does not have to part with its own funds until payment is made and it is forced to reimburse the issuing bank. ${ }^{47} \mathrm{Be}-$ cause the cash-flow burden might otherwise be prohibitive, this is a great advantage to a party who enters into a large number of transactions simultaneously. ${ }^{48}$ Moreover, the beneficiary is satisfied; while it does not actually possess the funds, as it would if a cash deposit were used, it is protected by the credit of a financial institution..$^{49}$

\section{Proposed Expansions of the Fraud in the Transaction EXCEPTION}

Since the development of modern letter of credit law in the nineteenth century, ${ }^{\mathrm{s} 0}$ courts have uniformly held that, as a general rule, the issuer's obligation under the letter of credit is independent of any defense the customer may have against payment on

4 U.C.C. $\S 5-114(3)$ (1978).

46 The Uniform Commercial Code does not require that notice be given to the customer when a demand for payment is made. Even where such a requirement has not been included in the terms of the letter of credit, however, the issuing bank will often use its three-day grace period for honoring a demand for payment, see id. \& 5-112(1), to notify the customer that a demand has been made.

47 Although the customer's assets may be encumbered by any security interest given to the bank, it still does not have to forgo the use of those assets.

4s See D. Policano, supra note 16, at 149-50.

49 It has been stated that the purpose of the letter of credit is to assure the beneficiary of the benefits of the bank's solvency and the absoluteness of the bank's obligations. See Justice, Letters of Credit: Expectations and Frustrations (pt. 1), 94 Banking L.J. 424, 42829 (1977).

so The modern law governing letters of credit was developed from the "law merchant." See Trimble, The Law Merchant and the Letter of Credit, 61 Harv. L. Rev. 981 (1948). It has been suggested that the origins of the letter of credit can be traced to ancient Syrian rug merchants, Phoenician traders, and the Mitsui Bank of old Japan. See Lambert, supra note 38 , at 17 . 
the underlying contract. ${ }^{51}$ Sztejn $v$. Henry Schroder Banking Corp. ${ }^{52}$ carved out the fraud in the transaction exception to this rule of absolute independence. In Sztejn, the customer contracted to buy bristles from an Indian corporation. In order to pay for the bristles, the customer obtained an irrevocable letter of credit in favor of the seller. ${ }^{53}$ The letter of credit required the issuing bank to pay the beneficiary upon the beneficiary's presentation of an invoice and a bill of lading covering the shipment. ${ }^{54}$ Instead of shipping the bristles required by the contract, the beneficiary allegedly placed fifty cases filled with trash on a ship, procured a bill of lading and invoices describing the bristles, as required by the letter of credit, and presented these documents and a conforming draft to the issuing bank and requested payment. ${ }^{.5}$ The court held that the customer was entitled to enjoin the bank from making payment under these circumstances because this controversy involved not a mere breach of warranty but an allegation of intentional failure to ship the goods. ${ }^{56}$

The fraud in the transaction exception created in Sztejn has been codified in section 5-114 of the Uniform Commercial Code, ${ }^{57}$

s1 See, e.g., Sisalcords Do Brazil, Ltd. v. Fiacao Brasileira De Sisal, S.A., 450 F.2d 419, 422 (9th Cir. 1971) (issuing bank "undertakes that it will honor drafts drawn and negotiated only in strict compliance with the terms of the letter"); Venizelos, S.A. v. Chase Manhattan Bank, 425 F.2d 461, 465 (2d Cir. 1970) ("[T] The letter of credit constitutes the sole contract of the bank with the seller and is completely independent of the other contracts."); Dulien Steel Prods. v. Bankers Trust, 298 F.2d 836, 841 (2d Cir. 1962) ("[It] seems well established that a bank issuing ... a letter of credit is not concerned with the underlying contract between the buyer and the seller.").

32177 Misc. 719, 31 N.Y.S.2d 631 (Sup. Ct. 1941).

${ }^{53}$ Id. at 720,31 N.Y.S.2d at 633 .

st Id.

ss Id.

so [W] and documents have been presented for payment, the principle of the independence of the bank's obligation under the letter of credit should not be extended to protect the unscrupulous seller ....

...

... Although the bank is not interested in the exact detailed performance of the sales contract, it is vitally interested in assuring itself that there are some goods represented by the documents.

Id. at 722-23, 31 N.Y.S.2d at 634-35.

82 This section provides in part:

Unless otherwise agreed when documents appear on their face to comply with the terms of a credit but a required document . . . is forged or fraudulent or there is fraud in the transaction ... (b) . . . an issuer acting in good faith may honor the draft or demand for payment despite notification from the customer of fraud, forgery or other defect not apparent on the face of the documents but a court of appropriate jurisdiction may enjoin such honor.

U.C.C. § 5-114(2) (1978). Reconciling the independence principle with the principle of 
and has been accepted by courts in England. ${ }^{58}$ In cases involving traditional letters of credit, the courts have given the fraud in the transaction exception a narrow reading, confining its application to cases of egregious fraud on the part of the beneficiary. ${ }^{59}$ This narrow reading apparently is justified on the ground that a broader rule would defeat the certainty of letter of credit transactions and undermine one of the basic purposes of the letter of creditassuring prompt payment to the beneficiary. ${ }^{60}$

Controversy has arisen, however, over the appropriate definition of fraud in the transaction in cases involving standby letters of credit. Some commentators have argued that the narrow exception to the independence rule, developed for traditional letters of credit, is inappropriate in the case of a standby letter of credit for two reasons. First, because the customer assumes that the beneficiary will act in good faith and because it is much easier, when no third-party documentation is required, for the beneficiary to make a knowingly or recklessly false demand, the narrow definition of fraud in the transaction can lead to unjust and unanticipated results. ${ }^{61}$ Second, commentators argue that the rule distorts the "bargain-in-fact" between the parties to the underlying contract

Sztejn is not a simple matter. Cf. Note, supra note 18, at 1003 (acknowledging the difficulty of reconciling the two principles).

Section 5-114 provides two methods by which payment on a letter of credit may be prevented in the event of fraud in the transaction. The customer may seek an injunction against the demand being honored from "a court of appropriate jurisdiction," and (by implication) the issuer is permitted to dishonor the demand when it is notified of fraud by the customer.

${ }^{88}$ See United City Merchants Ltd. v. Royal Bank of Can. (The American Accord), [1979] 1 Lloyd's L.R. 267, 275-77; Etablissement Esefka Int'l Anstalt v. Central Bank of Nig., [1979] 1 Lloyd's L.R. 445, 449.

${ }^{89}$ Exactly what constitutes "egregious fraud" has not been very well defined. It has been suggested that it is "outrageous conduct which shocks the conscience of the court." Symons, supra note 24, at 348. See generally Harfield, supra note 13, at 601-14 (analyzing Sztejn and noting its narrow application in subsequent cases); Note, supra note 14, at 48488 (suggesting that the fraud in the transaction exception has only been applied where the beneficiary's demand was politically motivated).

Bo An extreme example of this policy is shown by the California legislature's deletion, from its version of U.C.C. $\S 5-114(2)$ (b), of the words "but a court of appropriate jurisdiction may enjoin such honor," because of the legislature's belief that such a provision was fundamentally incompatible with the purpose of the letter of credit. See CaL. Com. CodE $\S 5114(2)$ \& n.6 (West 1984); see also Agnew v. FDIC, 548 F. Supp. 1234, 1238 (N.D. Cal. 1982) ("[T]o enjoin the issuing banks from paying on the letters of credit would directly contradict the intent of the legislature and erode the certainty that should accompany letter of credit transactions.").

B1 See Kimball \& Sanders, supra note 18, at 434-36 (discussing two cases, involving Iranian government agencies, that rejected risk-allocation arguments where bad faith was alleged). 
by requiring a bank to pay even when the customer has not in fact breached that contract. ${ }^{62}$

In response to these perceived shortcomings, courts and commentators have suggested two expansive interpretations of the fraud in the transaction exception: the "breach of contract" standard and the "intentional fraud" standard. The breach of contract standard would allow a customer to obtain an injunction against payment by proving that he has a valid defense to liability on the underlying contract. The intentional fraud standard would permit a court to enjoin payment when there is a showing that the beneficiary's demand was knowingly false. Both standards rest on the notion that an expansive definition of the fraud in the transaction exception will better preserve the parties' expectations when a standby letter of credit is involved.

\section{A. The Breach of Contract Standard}

Recently, a proposal was made for a major expansion in the fraud in the transaction exception for cases involving standby letters of credit. ${ }^{63}$ Under this proposed "breach of contract" standard, the customer would be allowed to obtain an injunction against payment by showing that it has a valid defense to an action for breach of the underlying contract. ${ }^{64}$

The argument for this standard rests upon the assumption that a standby letter of credit, unlike a traditional letter of credit, is employed by the parties to a contract not to alter their "bargainin-fact," but only to assure the beneficiary that this bargain-in-fact will not be destroyed by the customer's insolvency. ${ }^{65}$ Thus, courts should be permitted to intervene by enjoining payment on the standby letter of credit when such payment would destroy the bargain-in-fact. Under this view of the fraud in the transaction exception, a court should apply familiar principles of liability and excuse $^{68}$ to determine whether payment under the standby letter of credit is permissible and thereby effectively decide the merits of the underlying contractual dispute at the time a demand for payment under the standby letter of credit is made.

62 See, e.g., Note, supra note 18, at 1011-13.

is Id. at 1014-15.

ot Id. at 1014.

os This interpretation of the primary purpose of the standby letter of credit is accompanied by the assertion that the standby letter of credit should not be allowed to function as a "blank check" to the beneficiary. Id. at 1011-12.

so See id. at 1014. 


\section{B. The Intentional Fraud Standard}

Another expanded definition of the fraud in the transaction exception for standby letters of credit is the "intentional fraud" standard. This standard shares with the traditional "egregious fraud" standard the premise that a beneficiary who presents conforming documents under a letter of credit should only be prevented from receiving payment when his own wrongdoing has led to the creation of those documents. This standard departs from the traditional standard, however, by adopting a broader definition of "wrongdoing" than courts have been willing to apply in cases involving traditional letters of credit. Instead of enjoining payment under a letter of credit only if there has been "egregious" fraud, the intentional fraud standard would permit a court to enjoin payment if there has been (1) a false representation (2) fraudulently made (3) with the intention of inducing reliance. ${ }^{67}$

Professor Edward Symons advocates such an intentional fraud standard for both traditional and standby letters of credit. ${ }^{68} \mathrm{He}$ rejects the breach of contract standard because, in his view, it is a legitimate function of the letter of credit to shift the risk of innocent misconduct from one party to the other. The risk of an innocent failure by one party to comply with the terms of the underlying contract (such as a breach of warranty) constitutes an ordinary risk that the parties should be permitted to allocate as they please. ${ }^{69}$ Professor Symons distinguishes innocent misconduct from intentional wrongdoing, however, and asserts that "[i]t does not seem reasonable to presume that commercial parties, by contract, consciously shift the risk of intentional wrongdoing."

${ }^{87}$ See Symons, supra note 24, at 345; see also West Va. Hous. Dev. Fund v. Sroka, 415 F. Supp. 1107, 1114 (W.D. Pa. 1976) ("While the courts have been reluctant to define fraud, it generally is thought to include an element of intentional misrepresentation in order to profit from another.").

${ }^{68}$ Symons, supra note 24 , at $378-81$.

${ }^{69}$ Id. at 348 .

70 Id. at 348-49. Professor Symons finds support for his standard in the provisions of the Uniform Commercial Code. He first argues that the general good-faith provision contained in U.C.C. $\$ 1-203$ (1978) suggests that the beneficiary should not be able to profit from an intentional misrepresentation. Symons, supra note 24 , at 349-52. He then finds more specific support for the intentional fraud standard in U.C.C. \$ 5-114 (1978), which, in addition to setting forth the fraud in the transaction exception to the independence rule, permits injunction or dishonor of a demand for payment under a letter of credit if "a required document does not in fact conform to the warranties made on negotiation or transfer of a document of title (Section 7-507)." See Symons, supra note 24, at 365-69. Section 7-507 states that a person negotiating or transferring a document of title (which includes a bill of lading) warrants "that he has no knowledge of any fact which would impair its validity or worth." U.C.C. \$ 7-507(b) (1978). Thus, Professor Symons argues, if a beneficiary under a 
Although some important standby letter of credit cases appear to apply the fraud in the transaction exception more narrowly than would be required under the intentional fraud standard, ${ }^{71}$ other cases have applied what is in fact the intentional fraud standard. ${ }^{22}$ A recent example is Roman Ceramics Corp. v. Peoples National Bank, ${ }^{73}$ in which the customer contracted to buy ceramic decanters from the beneficiary and procured a standby letter of credit to cover payment for unpaid invoices on decanters shipped before September 1, 1979. The terms of the letter of credit allowed the beneficiary to obtain payment by presenting to the issuing bank a draft accompanied by the unpaid invoices and a certification that the invoices had not been paid. ${ }^{74}$

On October 9, 1979, the customer and the beneficiary discussed certain invoices (including five dated before September 1) that were overdue, and it was agreed that the customer would pay the overdue sum promptly. ${ }^{75}$ Six days later the beneficiary received

traditional letter of credit presented a bill of lading and a demand draft for payment to the bank with knowledge of a defect in the goods that would impair the worth of the bill of lading, the customer would be entitled to have payment enjoined. Symons, supra note 24, at 366-67. He concludes that this implicitly incorporates the intentional fraud standard into the definition of fraud in the transaction. Id. at 368 .

Professor Symons acknowledges that because standby letters of credit do not involve the presentation of documents of title, section 7-507 is inapplicable in these cases. Id. at 369. He nevertheless contends that the intentional fraud standard should apply to standby letters of credit by analogy: if the beneficiary knows that his certification of the customer's default is false, then the customer should be able to enjoin payment by the issuer. Id. He also suggests that section 5-111(1) of the Code requires this conclusion. Id. at 369-70. That section provides that "[u]nless otherwise agreed the beneficiary by transferring or presenting a documentary draft or demand for payment warrants to all interested parties that the necessary conditions of the credit have been complied with." U.C.C. § 5-111(1) (1978). This section, however, unlike section 5-114, does not provide for an injunctive remedy.

${ }^{71}$ See, e.g., Dymamics Corp. v. Citizens \& S. Nat'l Bank, 356 F. Supp. 991, 999 (N.D. Ga. 1973) (a demand must have "absolutely no basis in fact" to be considered fraudulent); Intraworld Indus. v. Girard Trust Bank, 461 Pa. 343, 359, 336 A.2d 316, 324-25 (1975) (fraud must "so vitiate[l the entire transaction that the legitimate purposes of the independence of the issuer's obligation would no longer be served"); Stringer Constr. Co. v. American Ins. Co., 102 Ill. App. 3d 919, 924-25, 430 N.E.2d 1, 5-6 (1981).

${ }^{72}$ See, e.g., Rockwell Int'l Sys., Inc. v. Citibank, 719 F.2d 583, 588-89 (2d Cir. 1983) (where Iranian beneficiary had actual knowledge of the conditions excusing further performance by the American customer, beneficiary's written declaration that the customer had failed to comply with the terms and conditions of the contract held fraudulent); Harris Corp. v. National Iranian Radio \& Television, 691 F.2d 1344, 1355-56 (11th Cir. 1982) (same).

73 F.2d 1207 (3d Cir. 1983).

$34 \mathrm{Id}$. at 1209.

7s Id. at 1209-10. One of the invoices was dated August 14, 1979, and the other four were dated August 20, 1979. Roman Ceramics Corp. v. Peoples Nat'l Bank, 517 F. Supp. 526, 527 (M.D. Pa. 1981). 
payment for the invoices but, claiming that the agreement had lapsed, chose to allocate part of that payment to invoices dated after September 1, thus leaving unpaid the five invoices dated before September 1, which were covered by the letter of credit. ${ }^{76}$ The beneficiary then presented a conforming demand for payment of the invoices under the letter of credit; the issuing bank refused to pay on the ground that the invoices, contrary to the beneficiary's certification, had already been paid. ${ }^{77}$

The district court enjoined payment, finding that the beneficiary knew that the invoices covered by the letter of credit had been paid and thus, in misrepresenting this fact to the issuing bank, had attempted to be paid twice. ${ }^{78}$ The Third Circuit affirmed, citing the decision of the Pennsylvania Supreme Court in Intraworld Industries v. Girard Trust Bank ${ }^{79}$ for the applicable definition of fraud in the transaction: " [W] think that the circumstances which will justify an injunction against honor must be narrowly limited to situations of fraud in which the wrongdoing of the beneficiary has so vitiated the entire transaction that the legitimate purposes of the independence of the issuer's obligations would no longer be served." "80

This formulation of the fraud in the transaction exception is essentially the egregious fraud standard traditionally applied in cases involving letters of credit. ${ }^{81}$ It would ordinarily require that the fraud engaged in by the beneficiary be much more severe than what occurred here-for example, that the beneficiary actually enter into the transaction with intent to make a false demand or that the fraud be so apparent that it could be detected by the court with only a minimal investigation of the facts. ${ }^{82}$ Here, however, the "fraud" did not relate to the transaction that gave rise to the standby letter of credit, but instead centered around the beneficiary's allegedly deliberate misinterpretation of the October 9 agreement; furthermore, the district court engaged in an extensive factual inquiry before concluding that there was fraud..$^{83}$ By hold-

78714 F.2d at 1210.

"7. Id. at 1210.

${ }^{78}$ Roman Ceramics Corp. v. Peoples Nat'l Bank, 517 F. Supp. 526, 536 (M.D. Pa. 1981).

$79461 \mathrm{~Pa} .343,336$ A.2d 316 (1975).

so Roman Ceramics, 714 F.2d at 1212-13 n.12 (quoting Intraworld, $461 \mathrm{~Pa}$. at 359, 336 A.2d at 324-25).

82 See infra note 109.

${ }^{82}$ See cases cited supra note 71.

${ }^{83}$ See Roman Ceramics Corp. v. Peoples Nat'l Bank, 517 F. Supp. 526, 529-38 (M.D.

Pa. 1981) (discussing testimony taken at trial). 
ing that a knowingly unjustified demand for payment alone is sufficient to constitute fraud in the transaction, the Third Circuit was in fact applying an intentional fraud standard. ${ }^{34}$

\section{Defense of a Narrow Fraud in the Transaction EXCEPTION}

Underlying the recent proposals for an expanded definition of fraud in the transaction is a perception that contracting parties would not want to employ a standby letter of credit if a rule of absolute independence existed. These proposals assume, in other words, that a customer would never want to give a "blank check" to the beneficiary. ${ }^{85}$ Thus, the appropriate definition of fraud in the transaction depends to a large extent upon the merits of an absolute rule of independence: the more desirable an absolute rule, the more narrowly should fraud in the transaction be defined. This section of the comment will first demonstrate that an absolute rule of independence may in fact promote the interests of the contracting parties and will then evaluate the recent proposals in light of the benefits to be derived from a strict rule of independence. Finally, the comment will formulate a definition of fraud in the transaction that retains all the benefits of an absolute independence rule while preventing flagrant abuses where it is appropriate to do so.

\section{A. The Utility of an Absolute Rule of Independence}

Consider the following hypothetical standby letter of credit transaction. Beneficiary, a corporation, and Customer, a building contractor, enter into a contract under which Customer is to construct an office building in Japan for a contract price of five million dollars. Beneficiary, wishing to be protected in the event that Customer fails to perform, requires Customer to obtain a standby letter of credit in Beneficiary's favor in the amount of $\$ 500,000$.

84 A dissenting opinion in Roman Ceramics argued that the majority's decision would "increase the pressure on financial institutions to dishonor letters of credit, thus making less certain the underpinnings of many commercial transactions." $714 \mathrm{~F} .2 \mathrm{~d}$ at 1216 (Adams, J., dissenting). The dissent objected to the court's finding that an oral agreement reached after one party had fully performed was so connected with the letter of credit as to be an implied term; a knowingly unjustified demand should not, by itself, be sufficient to constitute fraud in the transaction. Id. at 1218-19.

ss See Note, supra note 18, at 1012-13; Note, Guaranty Letters of Credit: Problems and Possibilities, 16 ARIz. L. REv. 822, 839-40 n.113 (1974) (questioning "why presumably knowledgeable commercial parties would write such terms into their security arrangements"). 
Under the terms of the standby letter of credit, Beneficiary is entitled to payment when it presents to the issuing bank a written statement that Customer has defaulted upon the contract. Assuming either that no fraud in the transaction exception to the rule of independence existed or that the parties were unaware of such an exception, ${ }^{86}$ would the parties be willing to enter into such an arrangement?

This arrangement has obvious advantages for Beneficiary. If Customer defaults, Beneficiary can receive what are in effect liquidated damages without incurring any litigation costs. Moreover, Beneficiary does not bear the judgment and execution risks that would ordinarily be borne by a party who has the burden of going forward with litigation: Beneficiary avoids the risks that it will lose on procedural grounds or because of the erroneous application of substantive law by a trial court, it avoids evidentiary problems that may weigh heavily against the party having the burden of proof, and it avoids potential difficulties in obtaining satisfaction of any judgment it might obtain. ${ }^{87}$ The standby letter of credit shifts all these risks to Customer. Customer also bears the risk that Beneficiary will demand payment without justification-that is, that Beneficiary will assert that Customer has defaulted when it knows that Customer has complied with the terms of the contract.

At first glance, it might appear that neither party would want to contract for this arrangement. If Beneficiary is acting in good faith, it has no intention of making an unjustified demand and therefore would not be expected to bargain for the power to make one. Because Customer and the issuing bank will demand compensation for assuming the risk of such a demand being made, the contract price would be increased without any apparent corresponding benefit to Beneficiary. It also appears unlikely that Customer would be willing to assume the risk of an unjustified de-

\footnotetext{
${ }^{86}$ For a number of reasons, such an absolute rule seems to comport with the the parties' expectations. First, because the fraud in the transaction exception has been given a narrow reading by the courts, parties might reasonably expect that something close to an absolute rule of independence would be applied. Second, the typical standby letter of credit does not expressly provide for notice to the customer when payment is demanded, see Kimball \& Sanders, supra note 18, at 430 (discussing cases where customers asked courts to read in such a notice requirement where letter of credit was silent on the matter); thus, in many instances the bank will simply pay on a conforming demand and there will be no possibility that an issue of fraud will arise. Furthermore, it appears that parties who use standby letters of credit are usually well aware of the risks posed by standby letters of credit. See Lambert, supra note 38, at 18. But see Ellinger, Fraud in Documentary Credit Transactions, 1981 J. Bus. L. 258, 266 (denying that such awareness exists).
}

${ }^{87}$ See Note, supra note 14 , at 472-73. 
mand. Customer would certainly require that he be given additional compensation for assuming this risk; but because the risk includes the possibility of Beneficiary's deliberately making a false demand, it would seem impossible to calculate an adequate amount of compensation. ${ }^{88}$

This analysis is incorrect, however, because it fails to take into account the positions of the parties before they agree to the use of a standby letter of credit. In fact, Beneficiary benefits from an absolute rule of independence for three reasons. First, the issuing bank may charge a smaller fee for the standby letter of credit because it knows that it will not become embroiled in litigation with the beneficiary if it is requested to pay under a conforming demand. ${ }^{89}$ The reduction in the cost of the standby letter of credit may in turn be passed on to Beneficiary through a reduction in the price of the underlying contract. Second, Beneficiary is assured that Customer will not be able to hold up payment on the standby letter of credit by alleging that a good-faith demand was in fact made in bad faith. Third, Beneficiary also protects itself against the possibility that a court will mistakenly enjoin payment by finding that its honest demand was made in bad faith. ${ }^{90}$

Customer also benefits from the use of a standby letter of credit under an absolute rule of independence. It is simplistic to conclude either that Customer would agree to the use of the standby letter of credit only out of ignorance of the consequences or that the transaction must be the result of superior bargaining power on the part of Beneficiary..$^{91}$ Customer will only agree to the use of a standby letter of credit if Beneficiary compensates him for the risk of an unjustified demand. ${ }^{22}$ If Customer believes that Beneficiary would be likely to demand payment without justification, the compensation it would require would be so high that Beneficiary would be unwilling to enter into the transaction. Thus, the parties will use the standby letter of credit only when Customer

s8 Thus, Professor Symons concludes that it is unreasonable to shift the risk of intentional behavior. See supra text accompanying note 70 .

89 See supra notes $39-41$ and accompanying text.

9o Under a broad fraud in the transaction exception, for example, a court might assume that because allegations of the falsity of a demand were brought to the beneficiary's attention, the subsequent demand was necessarily made in bad faith. See e.g., Shaffer v. Brooklyn Park Garden Apartments, 311 Minn. 452, 463, 250 N.W.2d 172, 179 (1977) (apparently equating allegations of false certification with allegations of fraud).

92 But see Note, supra note 14, at 494-95; Note, supra note 85, at 839 n.113.

92 See, e.g., Edward Owen Eng'g v. Barclays Bank Int'l, [1978] 1 Lloyd's L.R. 166, 171 (C.A.) (the "possibility [of false demand] is so real that the . . . supplier, if he is wise, will take it into account when quoting his price"). 
has a high degree of confidence that Beneficiary will not make an unjustified demand for payment. When this is true, Beneficiary's trustworthiness, combined with the certainty of operation and reduced cost of the standby letter of credit, may make the overall expected cost of this arrangement lower than what the expected cost of the transaction would be in the absence of the standby letter of credit. Customer will still have to be compensated for the risk of an unjustified demand, but this compensation may now be small enough that Beneficiary prefers to use the standby letter of credit rather than some other risk-shifting device..$^{93}$

Critics of an absolute independence rule fail to consider adequately the position of the contracting parties from this ex ante perspective. Professor Symons' argument-that parties can be assumed not to want to shift the risk of intentional fraud ${ }^{94}$-is persuasive only in cases where the beneficiary is acting in bad faith from the outset. ${ }^{95}$ If the beneficiary is acting in good faith at the outset of the transaction, however, it may not be unreasonable for the customer to accept the risk that the beneficiary might later make a knowingly unjustified demand. ${ }^{96}$ The customer will be able to evaluate this risk by considering the beneficiary's reputation, the customer's prior dealings with the beneficiary, the beneficiary's desire to do business with the customer in the future, and the beneficiary's interest in maintaining its credibility in the business

${ }^{93}$ It may be that the optimal solution for the parties would be to use a standby letter of credit and have a third party generate the documents that the beneficiary must present for payment. See Kimball \& Sanders, supra note 18, at 436 (suggesting this alternative). While this increases the cost of the standby letter of credit, because the third party must be compensated, it decreases the risk that the beneficiary will make an unjustified demand. Such a solution may still be unsatisfactory to the beneficiary, however, because it also poses some risk that the beneficiary will not be able to collect when he has a legitimate demand. And the more burdensome the requirements for a demand become, the more the standby letter of credit begins to look like a performance bond, rather than a simple standby letter of credit.

94 See supra text accompanying note 70 .

${ }^{85}$ Thus, one court has held that the fraud in the transaction exception applies only to fraud in the factum and not to the making of a fraudulent demand on a letter of credit. Bossier Bank \& Trust v. Union Planters Nat'l Bank, 550 F.2d 1077, 1082 (6th Cir. 1977); see also Baker v. National Boulevard Bank, 399 F. Supp. 1021, 1024 (N.D. Ill. 1975) (issuer must pay on beneficiary's demand except where there has been fraud in the formation of the underlying transaction).

${ }^{86}$ Cf. Posner, The Rights of Creditors of Affiliated Corporations, 43 U. CHI. L. Rev. 499, 507-09 (1976) (discussing the risk assumed by the bondholders of a corporation that shareholders will deliberately reduce the value of their bonds, for example, by further borrowing, but noting that this risk may be worth assuming because of the net benefits of the transaction). 
community. $^{97}$

By focusing on the apparent injustice that results from the application of the independence rule in particular cases, critics ignore the utility of a strict rule in commercial transactions generally. ${ }^{98}$ If courts adopt an expansive definition of fraud in the transaction, it will be more difficult to evaluate the risks associated with the standby letter of credit. A broad definition would make it difficult to predict how a court will act in any of the large number of circumstances in which a demand for payment might be made. Yet one of the primary reasons for using a standby letter of credit is to structure a transaction so that the results will be predictable.

Moreover, a broad definition of fraud in the transaction increases the risk that payment will be frozen, at least temporarily, every time a dispute arises between the parties concerning the adequacy of the customer's performance. ${ }^{99}$ The cost of using standby letters of credit will also be increased because issuing banks will require additional compensation for the increased risk of becoming involved in these disputes. ${ }^{100}$ Thus, even if a narrow exception produces harsh results in some cases, customers ${ }^{101}$ may prefer to bear

97 In the Iranian cases, the American companies may have had a high degree of confidence that the Imperial Government would not make an unjustified demand: they were dealing with a sovereign government that had a strong interest in continuing commercial relationships with American firms. See Kimball \& Sanders, supra note 18, at 435-36.

${ }^{88}$ Although formal rules may ignore the bargain-in-fact in particular cases, adherence to such rules furthers the goal of promoting mutually beneficial transactions . . . . Because contracting parties have a strong incentive to order their transactions to conform to the specific rules, the parties themselves can mitigate the apparent imprecision of these rules.

Baird \& Weisberg, Rules, Standards, and the Battle of the Forms: A Reassessment of $\S 2-$ 207, 68 VA. L. REv. 1217, 1231 (1982); see also Note, A Reconsideration of American Bell International, Inc. v. Islamic Republic of Iran, 474 F. Supp. 420 (S.D.N.Y. 1979), 19 Colum. J. Transnat'L L. 301, 331 (1981) ("predictable legal results make it easier, not harder, for corporations to plan their transactions"); cf. Note, supra note 6 (arguing for a strict rule of documentary compliance).

"9 As one court stated:

[O]ne of the expected advantages and essential purposes of a letter of credit is that the beneficiary will be able to rely on assured, prompt payment from a solvent party; necessarily, a part of this expectation of ready payment is that there will be a minimum of litigation and judicial interference, and this is one of the reasons for the value of the letter of credit device in financial transactions.

New York Life Ins. v. Hartford Nat'l Bank \& Trust, 173 Conn. 492, 499, 378 A.2d 562, 566 (1977); see also Justice, Letters of Credit: Expectations and Frustrations (pt. 2), 94 BANKING L.J. 493, 506 (1977) ("[M]any . . . courts . . . fail to give adequate consideration to the expectations created by letters of credit and the consequences of decisions which frustrate those expectations.").

${ }^{100}$ But see Ellinger, supra note 86, at 265 (arguing that banks do not become real parties to such litigation).

${ }^{101}$ It is worth noting that most customers are large commercial entities and, as "repeat 
this risk (so long as they retain the freedom to bargain for appropriate compensation) to being forced into using some alternative, more expensive mechanism.

Critics of a strict rule of independence also underestimate the sophistication of the entities that use standby letters of credit. Those who engage in standby letter of credit transactions are usually large corporate or governmental entities with access to highquality counsel and are thus in a position to evaluate and respond to the risks involved. Because a strict rule of independence makes clear the initial allocation of risk between the parties, such a rule better enables these entities to fix prices or reallocate risk according to the requirements of a particular transaction.

\section{B. Weaknesses in the Alternative Proposals}

1. Breach of Contract. The breach of contract definition of fraud in the transaction would radically change the nature of the standby letter of credit. Most significantly, it would create the possibility of double litigation of the merits of the underlying contractual dispute: once when an injunction is sought against payment on the standby letter of credit, and a second time when a suit is brought on the contract itself. In the first trial, the court would have to decide whether the beneficiary had breached the contract in order to determine whether there is a basis for an injunction. Regardless of who prevailed in that action, the losing party would be free to relitigate the same issue in an action based on the underlying contract. ${ }^{102}$ Under such an approach, the standby letter of credit would in effect be converted into a performance bond. ${ }^{103}$ But the performance bond already exists as an alternative to the

players," may end up being beneficiaries under standby letters of credit in other transactions.

${ }_{102}$ In some jurisdictions, collateral estoppel may be available to the party prevailing in the injunction action. See, e.g., Parklane Hosiery Co. v. Shore, 439 U.S. 322, 331 (1979) (holding that there is broad discretion in federal courts to decide if collateral estoppel may be used offensively in a given case). Of course, this would tend to raise the stakes for both parties in the injunction proceeding, resulting in more hard-fought, and expensive, litigation. At any rate, a second trial would often be necessary on contractual issues not tied to the letter of credit.

${ }^{103}$ Under such a provision, standby [letters of credit] would still guarantee payment to the beneficiary by substituting the bank's solvency for the customer's, but would no longer put the customer at risk when the contract breaks down through no fault of his own. The standby [letter of credit] would function more like the surety bond it replaces and would still retain the low-cost advantages of the letter of credit, since an issuing bank would still deal exclusively in documents and would remain privileged to pay on conforming documents unless enjoined.

Note, supra note 18, at 1014. 
standby letter of credit. For three reasons, it is also better suited to its purpose than a modified standby letter of credit. First, the cost of resolving disputes is likely to be lower when a performance bond is used because surety companies typically resolve disputes with an informal process that is less expensive than formal litigation. ${ }^{104}$ Second, because surety companies monitor the performance of the contract on an ongoing basis, they are able to take appropriate action more quickly and efficiently than is possible by seeking a judicial injunction. Third, the issuer cannot step into the customer's shoes and remedy a defect in performance, as a surety would do whenever such action would be less costly than the payment of damages. ${ }^{105}$

In addition to turning the standby letter of credit into an inferior version of the performance bond, the breach of contract standard would decrease the usefulness of standby letters of credit in another way. If issuing banks became involved in more litigation under this standard, their expenses would be increased and this added cost would be passed on, in the form of higher fees, to those who use standby letters of credit. This would decrease the utility of standby letters of credit generally.

The breach of contract standard would also deprive the parties to a contract of a mechanism for shifting the risks of litigation. One of the risks that would no longer be transferable would be the burden of pursuing litigation in a distant forum. For example, assume that an American customer obtains a standby letter of credit from an American bank in favor of an English beneficiary, and that the underlying contract provides that all contractual disputes are to be adjudicated in English courts. When the beneficiary seeks to draw on the standby letter of credit, the customer seeks an injunction in an American court. Under the breach of contract standard, an American court will in fact be adjudicating the merits of the underlying dispute, and the English beneficiary will be forced to litigate in a distant forum, contrary to the agreement between the parties. Furthermore, if the customer wins, the English beneficiary will be forced to pursue its action for damages on the underlying contract in an American court. Thus, under the breach of contract standard, an American company dealing with a foreign party would no longer be able to assume "the risk of political uncertainty and governmental caprice." ${ }^{106}$ Foreign beneficiaries might

10 See Garman, supra note 17 , at 7-8.

105 See supra notes 31-35 and accompanying text.

${ }^{106}$ See American Bell Int'l v. Islamic Republic of Iran, 474 F. Supp. 420, 426 (S.D.N.Y. 
decide that the standby letter of credit no longer provides the security they desire and either look for a new instrument to achieve the same purposes or refuse to deal with American companies altogether. ${ }^{107}$

2. Intentional Fraud. For three reasons, the intentional fraud standard proposed by Professor Symons ${ }^{108}$ and applied in such cases as Roman Ceramics ${ }^{109}$ leads to unsatisfactory results. First, under the intentional fraud standard, an issuing bank is not required to show that the customer lacked an adequate alternative remedy ${ }^{110}$ in order to prevail in an action for wrongful dishonor on

1979).

${ }^{107}$ See Note, supra note 14, at 495; see also Justice, supra note 99, at 507 (suggesting that beneficiaries might switch to other arrangements, including cash deposits, if they could not rely on letters of credit). One commentator has suggested:

[T] here are proposals afoot to amend Article 5 to ... facilitate attacks on standby credits by integrating them into the underlying contract and breaking the rule of independence. The effect of that will be to drive creditors back to twenty-page guarantees containing elaborate clauses by which the guarantor waives all the defenses of his principal. The game seems hardly worth the candle.

Becker, supra note 37, at 346-47 (footnote omitted). It is worth noting that English courts observe a very strict rule of independence in cases involving standby letters of credit. See Edward Owen Eng'g v. Barclays Bank Int'l, [1978] 1 Lloyd's L.R. 166, 171-72 (C.A.).

${ }^{208}$ See supra notes $67-70$ and accompanying text.

100714 F.2d 1207 (3d Cir. 1983) (discussed supra notes 73-84 and accompanying text). The Roman Ceramics court purported to follow the standard set forth in Intraworld Indus. v. Girard Trust Bank, 461 Pa. 343, 359, 336 A.2d 316, 324-25 (1975). See supra text accompanying note 80 . This standard has been adopted in a number of jurisdictions. See, e.g., Stringer Constr. Co. v. American Ins. Co., 102 Ill. App. 3d 919, 924-25, 430 N.E.2d 1, 5-6 (1981). Intraworld, however, did not establish an intentional fraud standard. Because the beneficiary in that case had a bona fide claim for payment, the court denied an injunction against payment. The court did not indicate that a knowingly unjustified demand would be a sufficient basis for an injunction. It merely stated that "[a]n injunction is proper only if [the beneficiary], comparable to the beneficiary in Sztejn, has no bona fide claim to payment under the lease." Intraworld, $461 \mathrm{~Pa}$. at 361, $336 \mathrm{~A} .2 \mathrm{~d}$ at 325 . The conduct of the beneficiary in Sztejn, however, was much more than a mere knowing misrepresentation: it was a clear attempt to collect on the letter of credit without performing at all and without any intention of litigating the issue of liability under the contract. Indeed, it would seem that under the Intraworld test a court is bound to determine whether a beneficiary's knowingly unjustified demand is one that could not be encompassed within the legitimate purposes of the independence rule. Since shifting the risk of a knowingly unjustified demand is within the legitimate purposes of the independence rule, see supra notes 89-97 and accompanying text, the Intraworld test would seem to require a narrower standard than intentional fraud. See New York Life Ins. Co. v. Hartford Nat'l Bank \& Trust Co., 173 Conn. 492, 501, 378 A.2d 562, 567 (1977) (Intraworld test will justify dishonor only in rare situations of egregious fraud); Stringer Constr. Co. v. American Ins. Co., 102 Ill. App. 3d 919, 925, 430 N.E.2d 1, 6 (1981) (same).

110 An "adequate remedy at law" is one of the normal prerequisites for an injunction that should be applied in the standby letter of credit situation. See, e.g., Shaffer v. Brooklyn Park Garden Apartments, 311 Minn. 452, 467, 250 N.W.2d 172, 181 (1977); Werner v. A.L. Grootemaat \& Sons, Inc., 80 Wis. 2d 513, 520, 259 N.W.2d 310, 313-14 (1977). But see In re Pine Tree Elec. Co., 16 Bankr. 105, 107 (Bankr. D. Me. 1981) (injunction may issue on 
a standby letter of credit. The lack of such a requirement, however, only serves to undermine important purposes of the standby letter of credit-shifting the risk of litigation and avoiding expensive premature procedures that test the propriety of a demand-by breeding unnecessary litigation. In Roman Ceramics, for example, the involved factual inquiry engaged in by the trial court should have been foreclosed, by summary judgment, on the ground that the customer had an adequate remedy at law. If the customer's contention (that, by agreement with the beneficiary, the invoices covered by the standby letter of credit had in fact been paid) were true, then the customer would have had a valid cause of action against the beneficiary for breach of contract. By deciding the merits of the controversy at the time payment was sought on the standby letter of credit, the decision merely shifted back to the beneficiary the burden of bringing his own action for payment of the invoices covered by the standby letter of credit. Thus, an unnecessary additional trial would be required and the risk-shifting function of the standby letter of credit defeated.

Second, the intentional fraud standard is unsatisfactory because it requires an inquiry into the intent of the beneficiary in making the demand. While intent is easy to allege, it is a difficult issue to litigate. This decreases the usefulness of the standby letter of credit to the beneficiary because it decreases the certainty of operation of the standby letter of credit, even where the beneficiary acts in the best of faith. Many cases may simply come down to the customer's word against the beneficiary's. In such situations, the beneficiary must rely on the trier of fact to evaluate the parties' demeanor correctly. Even if a court ultimately rejects the customer's position, the mere fact that the customer could be expected to be able to get into court with a bare allegation of intentional fraud will reduce the beneficiary's confidence in the protection afforded by the standby letter of credit. ${ }^{111}$ Under a rule of absolute independence, however, the beneficiary avoids this uncertainty: by possessing the power to make a bad faith demand, the beneficiary is better protected when it makes a good faith demand.

Third, the intentional fraud standard permits the customer to avoid the consequences of a risk that it has knowingly incurred. The utility of the standby letter of credit is highest when it is subject to a strict rule of independence and its use is limited to situa-

substantiated allegation of fraud without a showing of an inadequate remedy at law).

11 See Justice, supra note 49, at 439. 
tions in which the customer trusts the beneficiary not to make knowingly unjustified demands. ${ }^{112}$ In such cases, the parties can evaluate the risks that have been allocated and adjust the compensation accordingly. The intentional fraud standard is thus likely to be applied accurately only in situations where the customer could have foreseen the possibility of a knowingly unjustified demand at the outset of the transaction. In such cases, however, the customer could have insisted on the use of an alternative risk-shifting mechanism-such as a performance bond-that does not carry with it the possibility of knowingly unjustified payment: ${ }^{113}$ A customer that procures a standby letter of credit when it does not trust the beneficiary is permitted, under the intentional fraud standard, to avoid the consequences of incurring a foreseeable, and avoidable, risk.

\section{Defining Fraud in the Transaction for Standby Letters of CREDit}

The foregoing analysis demonstrates that an expansive definition of fraud in the transaction undermines the utility of the standby letter of credit. Moreover, a comparison of the function of standby letters of credit with that of traditional letters of credit suggests that fraud in the transaction should be defined even more narrowly for standby than for traditional letters of credit. ${ }^{114}$ The standby letter of credit is primarily a risk-shifting device, with the advantage of providing the beneficiary with swift and easy access to funds in case of a default by the customer, much as if the customer had left a cash deposit with the beneficiary. ${ }^{115}$ The standby

112 As one English judge has suggested:

In effect, the sellers rely on the probity and reputation of their buyers and on their good relations with them. But this trust is inevitably sometimes abused, and . . . such guarantees are sometimes drawn upon, partly or wholly, without any or any apparent justification, almost as though they represented a discount in favour of the buyers. In such cases the sellers are then left merely with claims for breaches of contract against their buyers and the difficulty of establishing and enforcing such claims.

R.D. Harbottle (Mercantile) Ltd. v. National Westminster Bank, [1977] 3 W.L.R. 752, 756 (Kerr, J.).

${ }^{113}$ A customer could also avoid much of this risk by requiring that the documents necessary for a conforming demand be produced by a third party. See supra note 93 .

${ }_{114}$ See Dynamics Corp. v. Citizens \& S. Nat'l Bank, 356 F. Supp. 991,999 (N.D. Ga. 1973) (suggesting that a narrower definition of fraud in the transaction is appropriate for the standby letter of credit because of the greater difficulty of determining the truth or falsity of the beneficiary's demand under a standby than under a traditional letter of credit). But see Note, supra note 18, at 1014 (arguing that a broader definition of fraud in the transaction should apply to standby than to traditional letters of credit).

${ }^{115}$ See supra text accompanying notes 44-46; see also supra note 42 and accompanying 
letter of credit is often preferable to a cash deposit, however, because it does not require the customer to part with any funds until after payment is demanded on the standby letter of credit. ${ }^{116}$ Just as there is a risk that a cash deposit will be misappropriated, however, there is a foreseeable risk that an unjustified demand will be made under a standby letter of credit. The parties must take this risk into account in deciding whether to use the standby letter of credit instead of alternative risk-shifting mechanisms. ${ }^{117}$

The traditional letter of credit, on the other hand, is primarily a payment mechanism, designed to prevent a seller from having the benefit of payment before it has met its obligation under the contract. Unlike the parties in a standby letter of credit transaction, the parties to a traditional letter of credit expect the beneficiary to draw on the letter of credit eventually. They do not normally anticipate that an unjustified demand for payment may be made. Because the possibility of an unjustified demand is less foreseeable in a traditional letter of credit transaction than it is in the standby letter of credit situation, it is more appropriate to impose a check against unjustified payment in cases involving traditional letters of credit.

This conclusion is reinforced by a comparison of the mechanisms for payment under each instrument. Payment under a standby letter of credit is normally conditioned solely on the beneficiary's assertion. The words the beneficiary must use are like keys that unlock the funds held by the bank; it is not necessary that the words be true. ${ }^{118}$ By contrast, the terms of a traditional letter of credit usually require the beneficiary to present a document-a bill of lading - that must be generated by a third party. Thus, unlike the beneficiary of a standby letter of credit, the beneficiary of a traditional letter of credit cannot obtain unjustified payment merely by a pro forma declaration. He must either deceive or corrupt the issuer of the bill of lading. The fraud inherent in such conduct is greater than that inherent in a knowingly unjustified

text (performance bonds not available as an alternative through banks).

116 See supra text accompanying note 49.

117 Moreover, in many cases there is likely to be no satisfactory alternative to the traditional letter of credit, and the transaction will not be entered into at all if a letter of credit is not satisfactory.

118 See First Nat'I Bank v. Rosebud Hous. Auth., 291 N.W.2d 41, 45 (Iowa 1980) (bank not allowed to dishonor on ground that demand, the wording of which was based on an earlier agreement that was subsequently modified by the customer and the beneficiary, was therefore false in some particulars). 
demand under a standby letter of credit. ${ }^{119}$ It is also more difficult to evaluate the risk of such fraud ex ante because it depends on the collusion or deceit of parties who are strangers to the underlying transaction. ${ }^{120}$

It is thus appropriate that the fraud in the transaction exception, as applied to standby letters of credit, be given a narrower definition than the fraud standard applicable to traditional letters of credit. Such a definition must also be strict enough to avoid undermining the utility of the standby letter of credit. In order to preserve the utility of the standby letter of credit, at least two requirements should be met before a customer may obtain an injunction against payment: (1) that the customer lack an adequate alternative remedy and (2) that there be no reasonable basis for the beneficiary's demand.

In permitting an exception to the absolute independence rule for standby letters of credit, it is essential that such an exception not preclude the shifting of risks that is a primary purpose of using a standby letter of credit. One of these risks is the burden of going forward with litigation. ${ }^{121}$ If a customer has an adequate alternative remedy-for example, an action under section 5-111(1) of the Uniform Commercial Code ${ }^{122}$ to recover sums unjustifiably paid

119 An example of the type of strategic behavior that may occur under a traditional letter of credit may be found in Prutscher v. Fidelity Int'l Bank, 502 F. Supp. 535 (S.D.N.Y. 1980). There the beneficiary claimed that the bill of lading indicating shipment of all the goods was true because it was issued when all the goods had been loaded onto a ship, even though some of the goods were subsequently returned to the warehouse before being shipped separately. Id. at 536.

${ }^{120}$ This distinction is reflected in section 5-114 of the Uniform Commercial Code, which allows injunction against or dishonor of payment on a letter of credit if a beneficiary presents a document of title with knowledge of any fact impairing its validity or worth. U.C.C. § 5-114(2) (1978) (incorporating id. § 7-507). There is no comparable provision for a document that consists merely of the beneficiary's assertion. Professor Symons argues that such a provision exists in section 5-111(1), which states that a beneficiary presenting a demand for payment warrants that the conditions of the credit have been complied with. Symons, supra note 24, at 369-70; see supra note 70. Section 5-111 does not create an injunctive remedy, however, and it is not mentioned in section 5-114. Furthermore, Professor Symons' argument proves too much. Section 5-111 is not limited to a warranty of the beneficiary's good faith; it implies a warranty that the actual conditions of the credit have been met. If section 5-111 were not limited to providing a remedy for damages for an unjustified demand, but were also to be the basis for injunction or dishonor, then it would in effect incorporate the breach of contract standard into the definition of fraud in the transaction. Such a standard would frustrate the purpose of the standby letter of credit, see supra notes 102-07 and accompanying text, however, and could not have been intended by the draftsmen of the Code.

${ }^{121}$ See supra notes 106-07 and accompanying text.

${ }_{122}$ U.C.C. $\$ 5-111(1)$ (1978) ("Unless otherwise agreed the beneficiary by transferring or presenting a documentary draft or demand for payment warrants to all interested parties 
under the standby letter of credit and an action for a breach of the underlying contract-then permitting an injunction against payment merely serves to place the burden of going forward with litigation on the beneficiary. This is precisely the risk that a beneficiary seeks to avoid in using a standby letter of credit. ${ }^{23}$

The existence of an adequate alternative remedy should be sufficient to deter the kind of egregious fraud that initially gave rise to the fraud in the transaction exception, thus preventing the standby letter of credit from being used as a tool for perpetrating fraud in that class of cases where the customer has mistakenly evaluated the trustworthiness of the beneficiary. In many instances, however, determining whether a customer has an adequate alternative remedy could itself require extended litigation and lead to the kind of delay in payment that the parties seek to avoid by using a standby letter of credit. Thus, to preserve the utility of the standby letter of credit, a second requirement for finding fraud in the transaction must be imposed: the customer must show that there is no reasonable basis for the beneficiary's demand. If the dispute between the customer and beneficiary involves a difficult issue of fact or of law, ${ }^{124}$ then the customer should lose, even though the preponderance of the evidence or weight of legal authority may be on the customer's side. As long as the beneficiary's position is one that could be held in good faith, a court should not proceed to determine whether it is in fact correct or whether the beneficiary actually holds it in good faith. This requirement preserves the utility of the standby letter of credit because it keeps litigation costs low: the only time a suit could be maintained is when it is clear on the face of the pleadings that the beneficiary's

that the necessary conditions of the credit have been complied with").

${ }^{123}$ Moreover, an adequate alternative remedy should include an action in any forum required by the underlying contract. Thus, for example, if the underlying contract between an Iranian beneficiary and an American customer requires that all disputes be heard in Iranian courts, the customer should ordinarily not be able to assert that it has no other adequate remedy: this was a risk it knowingly incurred. In the special case where the customer entered into the transaction with the Imperial Government of Iran itself at a time when neither party could have foreseen the possibility of a political revolution, an adequate alternative remedy may be found not to exist. See cases cited supra note 18; Comment, supra note 18 , at $242-43$.

124 See, e.g., First Arlington Nat'l Bank v. Stathis, 90 IIl. App. 3d 802, 804-07, 810-11, 413 N.E.2d 1288, 1290-93, 1295-96 (1980) (bank not allowed to dishonor on ground that beneficiary's conduct had the legal effect of releasing parties from liability and thus beneficiary's statement that a promissory note was due was false); Foreign Venture Ltd. Partnership v. Chemical Bank, 59 A.D.2d 352, 356, 399 N.Y.S.2d 114, 116 (App. Div. 1977) (refusing to consider whether operation of Australian bankruptcy law reduced indebtedness covered by letter of credit). 
position is untenable. Such a requirement would also deter customers from frivolously seeking to enjoin payment, again preserving the utility of the standby letter of credit by decreasing the probability that litigation would arise when a demand for payment is made.

These requirements for establishing fraud in the transaction-that there be no adequate alternative remedy and that there be no reasonable basis for the beneficiary's demand-can be used to give content to the fraud in the transaction exception without undermining the usefulness of the standby letter of credit. Many parties may decide that such strict requirements for preventing unjustified demands make the standby letter of credit an inappropriate device for particular transactions. In such cases, however, alternative risk-shifting devices (such as the performance bond) are available, and would probably be more appropriate in any event. A strict definition of fraud in the transaction would ultimately make the standby letter of credit more valuable where it is appropriate and thus preserve its usefulness in commercial transactions.

\section{Conclusion}

In the recent controversy over the appropriate scope of the fraud in the transaction exception in cases involving standby letters of credit, forceful arguments have been made for finding fraud in the transaction either when there has been a breach of the contract between the customer and the beneficiary or when there has been intentional fraud on the part of the beneficiary. Although facially plausible, both arguments suffer from the same flaw: a failure to analyze properly both the function served by the standby letter of credit in commercial transactions and the effect a broad exception would have on the overall utility of standby letters of credit. The standby letter of credit is useful in such transactions precisely because it allows the parties to shift the risk of unjustified demand from the beneficiary to the customer. This legitimate purpose can best be served by a narrow definition of fraud in the transaction. Thus, fraud in the transaction for standby letters of credit should be defined narrowly to require that the customer have no adequate alternative remedy and that there be no reasonable basis for the beneficiary's demand. 